\title{
GEJALA INTRUSI AIR LAUT DI DAERAH PESISIR PADELEGAN, PADEMAWU DAN SEKITARNYA
}

\section{INDICATION OF SEA WATER INTRUSION IN COASTAL PADELEGAN, PADEMAWU AREA}

\author{
Wisnu Arya Gemilang*, Gunardi Kusumah \\ Loka Penelitian Sumber Daya Kerentanan Pesisir, Balitbang KP, KKP \\ JL.Raya Padang-Painan km 16, Bungus, Padang \\ *Corresponding author e-mail: wisnu.gemilang@yahoo.co.id
}

Submitted: 18 Februari 2016 / Revised: 29 September 2016 / Accepted: 29 Oktober 2016

DOI: http://dx.doi.org/10.21107/jk.v9i2.1117

\begin{abstract}
In the part of Pademawu coastal areas, Pamekasan, was found brackish groundwater that spreading progressively. The purpose of this study was to map the distribution of salt to brackish groundwater, both in the shallow aquifer and the deep aquifer and also to find out the cause of the salinity of the ground water. Salt groundwater distribution was mapped based on the electrical conductivity (EC) with a salinity level criteria as established by Panitia Ad Hoc Intrusi Air Asin Jakarta. While the causes of groundwater salinity were analyzed based on hydrochemical facies with Trilinier Piper diagram. The results showed that the shallow groundwater aquifers slightly brackish to salt with $D H L$ value $>15,000 \mu S / \mathrm{cm}-50,000 \mu \mathrm{S} / \mathrm{cm}$ found in the southern part of Pademawu along the coast include Padelegan, Jumiang, Tanjung, Manjungan and Eastern Pademawu. As for the groundwater at deep aquifer entirely in fresh condition with $D H L$ value $<1500 \mu \mathrm{S} / \mathrm{cm}$, located in the northern part of the study area that include Tlanakan, Galis, Pamekasan and Larangan districts. Based on the DHL value, it shown that groundwater of the northern part of the study area was not affected by the sea water intrusion.
\end{abstract}

Keywords: Electric conductivity, sea water intrusion, aquifer, Pademawu

\section{ABSTRAK}

Sebagian wilayah pesisir Pademawu dan sekitarnya, Pamekasan, dijumpai adanya air tanah payau hingga asin dengan pelamparan yang cukup luas. Tujuan penelitian ini adalah untuk memetakan sebaran air tanah asin hingga payau tersebut, baik pada akuifer dangkal maupun akuifer dalam dan juga untuk mengetahui penyebab keasinan air tanah tersebut. Sebaran air tanah asin dipetakan berdasarkan nilai daya hantar listrik (DHL). Sedangkan penyebab keasinan air tanah dianalisa berdasarkan fasies hidrokimia dengan diagram Trilinier Piper. Hasil penelitian menunjukkan bahwa pada akuifer dangkal air tanah agak payau hingga asin dengan nilai DHL > $15.000 \mu \mathrm{S} / \mathrm{cm}-50.000 \mu \mathrm{S} / \mathrm{cm}$ dijumpai pada bagian Selatan Pademawu sepanjang pesisir pantai meliputi Padelegan, Jumiang, Tanjung, Manjungan dan Pademawu Timur. Sedangkan untuk air tanah dalam seluruhnya dalam kondisi tawar dengan nilai $D H L<1500 \mu \mathrm{S} / \mathrm{cm}$, berada pada bagian Utara dari daerah penelitian meliputi kecamatan Tlanakan, Galis, Pamekasan dan Larangan. Berdasarkan nilai DHL bahwa daerah bagian Utara penelitian tidak terdeteksi adanya proses penyusupan air laut pada air tanah.

Kata Kunci: Daya hantar listrik, Intrusi air laut, Akuifer, Pademawu 


\section{PENDAHULUAN}

Karakteristik ketersediaan airtawar di wilayah pesisir umumnya secara kuantitas memiliki air yang berlimpah, tetapi seringkali sulit mendapatkan air untuk berbagai penggunaan karena kualitasnya yang kurang memadai, namun di wilayah pesisir lain seringkali terdapat kesulitan untuk mendapatkan sumberdaya air tawar. Pengaruh laut terhadap tata air seringkali terlihat signifikan di wilayah pesisir, namun pengaruh tersebut berbeda di satu tempat dan tempat yang lain (Delinom et al., 2007). Hal ini terutama ditentukan oleh faktor alami, diantaranya faktor iklim dan bentuk wilayah. Pengaruh interaksi lautan telah merubah kualitas air tawar bercampur air laut sehingga menjadi payau bahkan asin.

Pertumbuhan kawasan pesisir Padelegan, Kecamatan Pademawu saat ini berkembang pesat terutama sektor perindustrian tambak garam yang dilakukan secara tradisional serta sektor perkebunan tembakau. Sejalan dengan hal tersebut kebutuhan akan air bersih terus meningkat, baik air untuk kebutuhan sehari-sehari maupun untuk kebutuhan industri. Untuk memenuhi kebutuhan air bersih tersebut, masyarakat lebih banyak mengandalkan air tanah, baik yang diambil dari akuifer dangkal maupun akuifer dalam. Eksploitasi air tanah yang terus berlangsung dan semakin meningkat dari waktu ke waktu diduga menjadi salah satu terjadinya intrusi air laut pada akuifer di daerah pesisir Padelegan. Hal ini ditunjukkan dengan semakin bertambahnya sumur penduduk yang berubah menjadi payau. Dalam banyak hal, intrusi air laut menimbulkan dampak yang sangat luas terhadap berbagai aspek kehidupan, seperti gangguan kesehatan, penurunan kesuburan tanah, kerusakan bangunan dan lain sebagainya (Saputra, 1998).

Penelitian dilakukan untuk mengetahui sebaran airtanah asin melalui peta zonasi air tanah asin berdasarkan hasil pengukuran di lapangan. Sedangkan analisis penyebab keasinan air tanah dilakukan melalui pendekatan analisa fasies hidrokimia yang tervisualisasikan pada diagram Trilinier Piper dan penentuan tingkat intrusi dengan metode Ratio Khlorida-Bicarbonat, sehingga dapat diketahui gejala intrusi air laut yang terjadi di daerah Pademawu dan Sekitarnya.

\section{MATERI DAN METODE}

Zona penelitian dilakukan pada beberapa area yang ada di Kabupaten Pamekasan meliputi kecamatan Pademawu, Tlanakan, Galis dan Larang (Gambar 1). Pembagian area lokasi pengamatan dan pengukuran airtanah tersebut berdasarkan zona pembagian litologi penyusun lokasi penelitian berdasarkan peta geologi lembar Waru - Sumenep, Jawa (Situmorang et al., 1992) sehingga dapat diketahui karakteristik airtanah pada masing - masing zona pengamatan dan memudahkan dalam proses pengklasifikasian kualitas airtanah. Titik lokasi pengukuran dan pengamatan kualitas air tanah tersebar secara merata dengan jumlah titik pengamatan sebanyak 65 titik, sehingga diharapkan dapat mewakili karakteristik air tanah pada tiap lokasi.

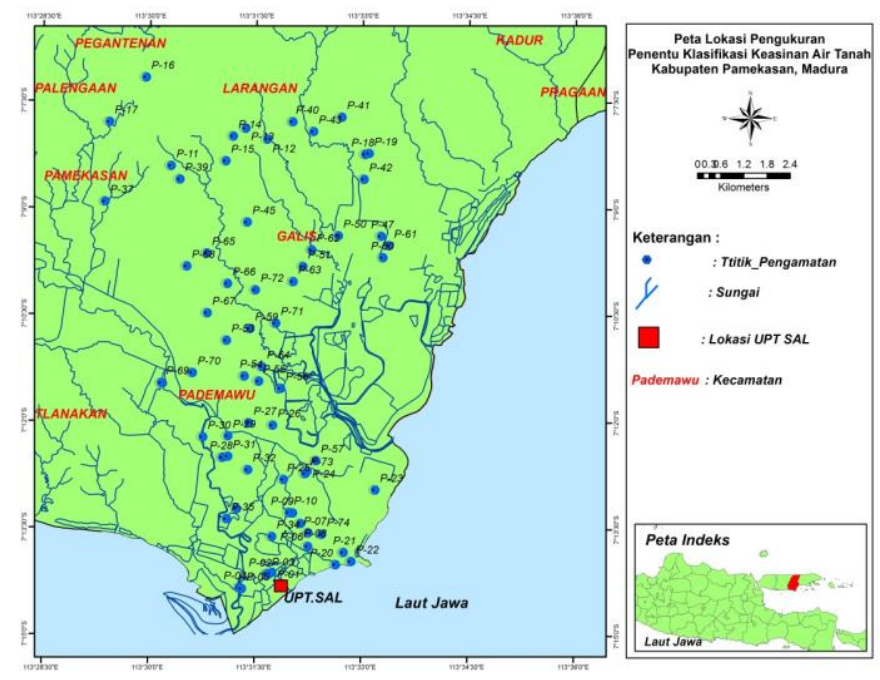

Gambar 1. Peta Lokasi Pengukuran 
Penelitian ini dilakukan dalam beberapa tahapan yaitu tahapan persiapan, berupa penyediaan alat dan bahan penelitian, tahap survey lapangan yaitu melakukan pengukuran nilai DHL menggunakan alat MultiParameter Water Quality Meter model WM22EP dan pengukuran kedalaman muka air tanah dengan meteran. Pengambilan sampel air tanah untuk selanjutnya di analisis di laboratorium Teknik Lingkungan ITB untuk menentukan nilai konsentrasi kation $(\mathrm{Na}, \mathrm{Ca}, \mathrm{Mg}$ dan $\mathrm{K}$ ) dan anion $(\mathrm{Cl}$, $\mathrm{SO}_{4}, \mathrm{CO}_{3}$ dan $\mathrm{HCO}_{3}$ ) sampel air tanah. Nilai kation maupun anion penyusun air tanah tersebut selanjutnya divisualisasi-kan dalam Diagram Trilinier Piper untuk mengetahui genesa air tanah tersebut (Mandel and Shiftan, 1981). Nilai DHL pada masingmasing titik sampel diplotkan dalam peta dasar untuk selanjutnya disusun peta zonasi sebaran air tanah asin. Dalam hal ini digunakan klasifikasi yang disusun oleh PAHIAA (1986) dalam Irham et al. (2006) sebagaimana tercantum pada (Tabel 1.).

Tabel 1. Klasifikasi keasinan air tanah

\begin{tabular}{lcc}
\hline Sifat Air & $\begin{array}{l}\text { Daya Hantar } \\
\text { Listrik }(\mathrm{DHL}) \\
(\mu \mathrm{S} / \mathrm{cm} / \mathrm{cm})\end{array}$ & $\begin{array}{l}\text { Kadar } \\
\text { Khlorida } \\
(\mathrm{mg} / \mathrm{lt})\end{array}$ \\
\hline Air Tawar & $<1.500$ & $<500$ \\
Air Agak & $1.500-5.000$ & $500-2.000$ \\
Payau & $5.000-15.000$ & $\begin{array}{c}2.000- \\
5.000\end{array}$ \\
Air Payau & 15.000-50.000 & $5.000-$ \\
Air Asin & 19.000 \\
$\begin{array}{l}\text { Brine } \\
\text { (connate) }\end{array}$ & $>50.000$ & $>19.000$ \\
\hline
\end{tabular}

(Sumber: PAHIAA (1986) dalam Irham et al. (2006)

Metode Diagram Trilinier Piper, prosentase kandungan anion dan kation dari berbagai stasiun digambarkan dalam satu diagram (Gambar 3). Pembagian fasies untuk kation meliputi tipe Magnesium (Mg), tipe Sodium $(\mathrm{Na}+\mathrm{K})$, dan tipe Calsium (Ca). Sedangkan fasies untuk anion meliputi tipe Sulfat (SO4), tipe Bicarbonat (CO3 + $\mathrm{HCO} 3)$, dan tipe Khlorida (Cl). Melalui diagram tersebut maka dapat digambarkan adanya percampuran dua jenis air yang berbeda sumbernya. Percampuran dua macam air yang berbeda sumbernya akan tergambar pada garis lurus yang menghubungkan dua titik yaitu titik air tawar dan titik air laut, sehingga dapat digunakan untuk mendeteksi adanya intrusi air laut.
Pada Metode Ratio Khlorida - Bicarbonat perbandingan ion digunakan sebagai dasar untuk mengetahui adanya penyusupan air laut. Perbandingan ion yang digunakan adalah perbandingan ion Khlorida terhadap ion Karbonat (Sihwanto, 1991). Hubungan antara tingkat penyusupan air laut dengan harga $\mathrm{R}$ (ratio khlorida-karbonat) dirumuskan sebagai berikut:

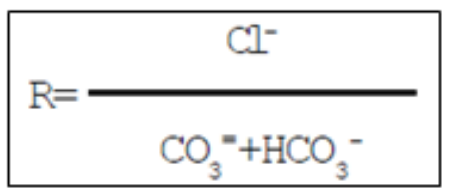

Dimana:

$\mathrm{Cl}$ - : konsentrasi ion khlorida (meq/liter)

$\mathrm{CO} 3$ : konsentrasi ion carbonat (meq/liter)

$\mathrm{HCO} 3$ : konsentrasi ion bicarbonate (meq /liter)

Dalam metode ini dinyatakan bahwa nilai perbandingan ion khlorida terhadap karbonat (nilai R) menunjukkan tingkat intrusi yang telah terjadi (Sihwanto, 1991) sebagaimana tercantum pada (Tabel 2).

Tabel 2. Hubungan Nilai $R$ dengan Tingkat Penyusupan Air Laut

\begin{tabular}{cl}
\hline Nilai $R$ & Tingkat Penyusupan Air Laut \\
\hline$<0,5$ & Air tanah tawar \\
$0,5-1,3$ & $\begin{array}{l}\text { Terjadi penyusupan air laut } \\
\text { sedikit }\end{array}$ \\
$1,3-2,8$ & $\begin{array}{l}\text { Terjadi penyusupan air laut } \\
\text { sedang }\end{array}$ \\
$2,8-6,6$ & $\begin{array}{l}\text { Terjadi penyusupan air laut } \\
\text { agak tinggi }\end{array}$ \\
$6,6-15,5$ & Terjadi penyusupan air laut \\
tinggi \\
$15,5-20$ & Air laut
\end{tabular}

(Sumber: Sihwanto, 1991)

\section{HASIL DAN PEMBAHASAN}

Survey lapangan yang telah dilakukan pada 65 titik pengamatan yang tersebar pada 5 Kecamatan yang ada di kabupaten Pamekasan yang meliputi kecamatan Pademawu, Tlanakan, Galis, Larangan dan Pamekasan. Kegiatan survey salah satunya yaitu melakukan pengukuran kedalaman muka airtanah sehingga dapat di peroleh kelompok area air tanah dangkal dan air tanah dalam seperti (Gambar 2). Daerah penelitian secara formasi geologi tersusun atas, tiga formasi batuan yaitu dari termuda 
endapan alluvial (Qa), Formasi Pamekasan (Qpp), Formasi Madura (Tpm) dan Formasi Ngrayong (Tmtn) (Situmorang et al., 1992), karena penentuan tipe akuifer tidak terlepas dari litologi penyusun dari suatu daerah. Tipe akuifer daerah penelitian dibagi menjadi dua jenis yaitu pada bagia selatan daerah penelitian masuk dalam kelompok akuifer tertekan (air tanah dangkal) dan tipe akuifer diatasnya adalah akuifer bebas (air tanah dalam).

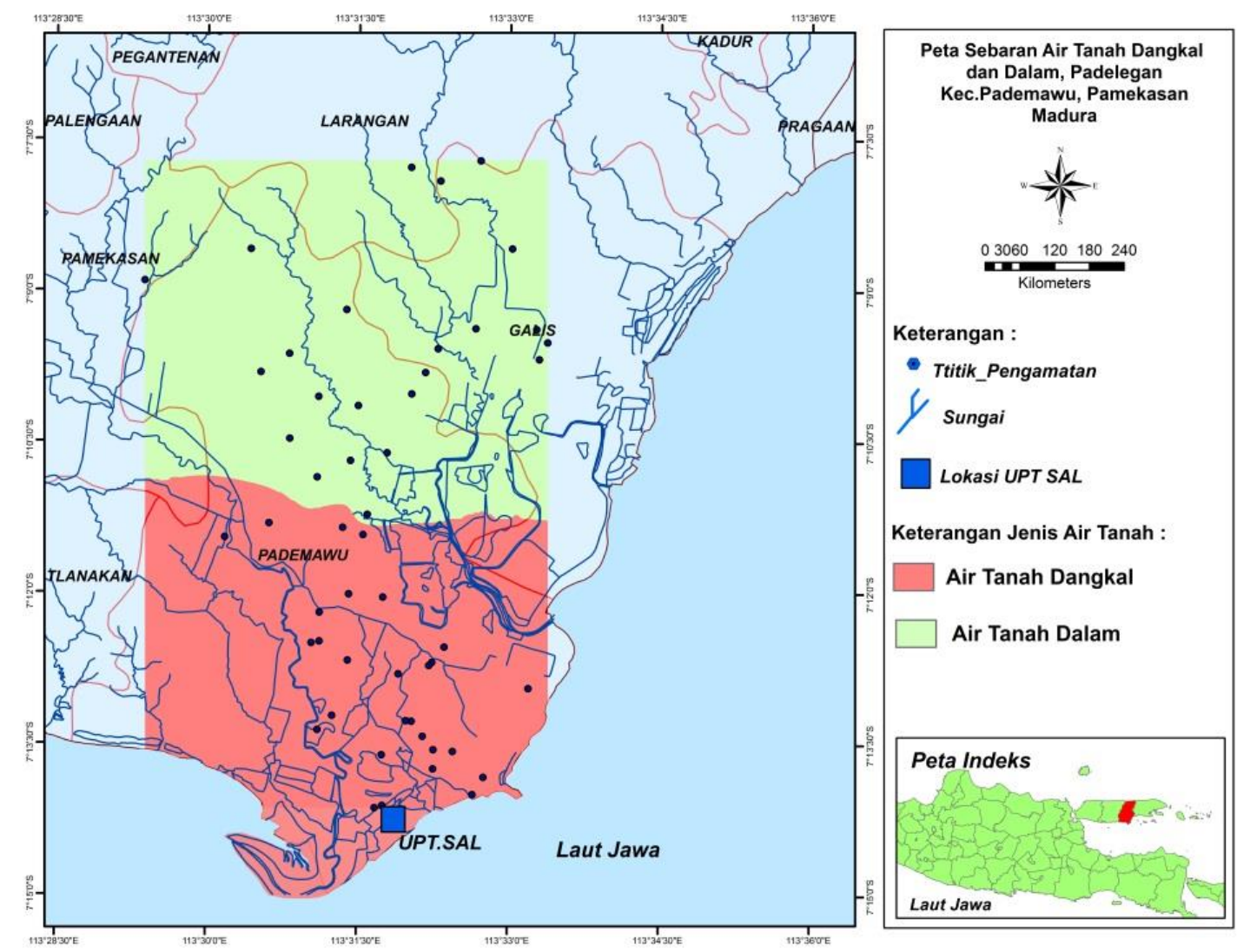

Gambar 2. Peta sebaran airtanah dangkal dan dalam di Padelegan, Kec. Pademawu

Pengukuran nilai DHL dilakukan pada beberapa sumur gali maupun sumur bor yang tersebar di bagian akuifer dangkal maupun akuifer dalam mengggunakan alat Multi-Parameter Water Quality Meter model WM-22EP. Hasil nilai pengukuran DHL kemudian di bentuk peta sebaran nilai $\mathrm{DHL}$ tersebut untuk mengetahui klasifikasi tingkat keasinan air tanah yang ada di daerah Pademawu dan Sekitarnya yang mengacu pada klasifikasi tingkat keasinan air tanah yang dikeluarkan oleh PAHIAA (1986) dalam Irham et al. (2006) (Gambar 3).

Berdasarkan peta sebaran nilai DHL yang ada di wilayah Padelegan dan Sekitarnya, terlihat bahwa air tanah asin pada akuifer dangkal di wilayah tersebut yaitu air tanah yang memiliki nilai DHL lebih dari 15000 $\mu \mathrm{S} / \mathrm{cm}$ yang terdapat di daerah Pademawu Timur, Tanjung, Daerah Pantai Jumiang dan Padelegan. Wilayah tersebut memiliki jarak dengan laut cukup dekat, namun pada beberapa tempat dilokasi tersebut juga masih ditemukan kondisi air yang bersifat payau dan tidak asin. Sedangkan daerah dengan air tanah bersifat payau memiliki nilai DHL lebih dari $5000 \mu \mathrm{S} / \mathrm{cm}$ berada di daerah Pantai Jumiang yang tidak berbatasan langsung dengan laut, Pademawu Timur dan Majungan. Secara umum kondisi air tanah yang bersifat asin dan payau berada pada bagian Selatan dan Tenggara daerah penelitian yang berbatasan langsung dengan laut.

Daerah sebaran air tanah asin hingga payau menempati akuifer berupa lempung pasiran yang merupakan endapan alluvial dengan permeabilitas umumnya rendah dan topografi permukaan tanah datar hingga landai, sehingga sangat rentan terhadap intrusi air laut. Beberapa lokasi juga memiliki kategori tingkat keasinan air tanah agak 
payau dengan nilai DHL lebih dari 1500

payau, yaitu di desa Pademawu, Majungan, $\mu \mathrm{S} / \mathrm{cm}$ berada diantara kelompok air tanah

Mansinan, Pokong dan Murtajih.

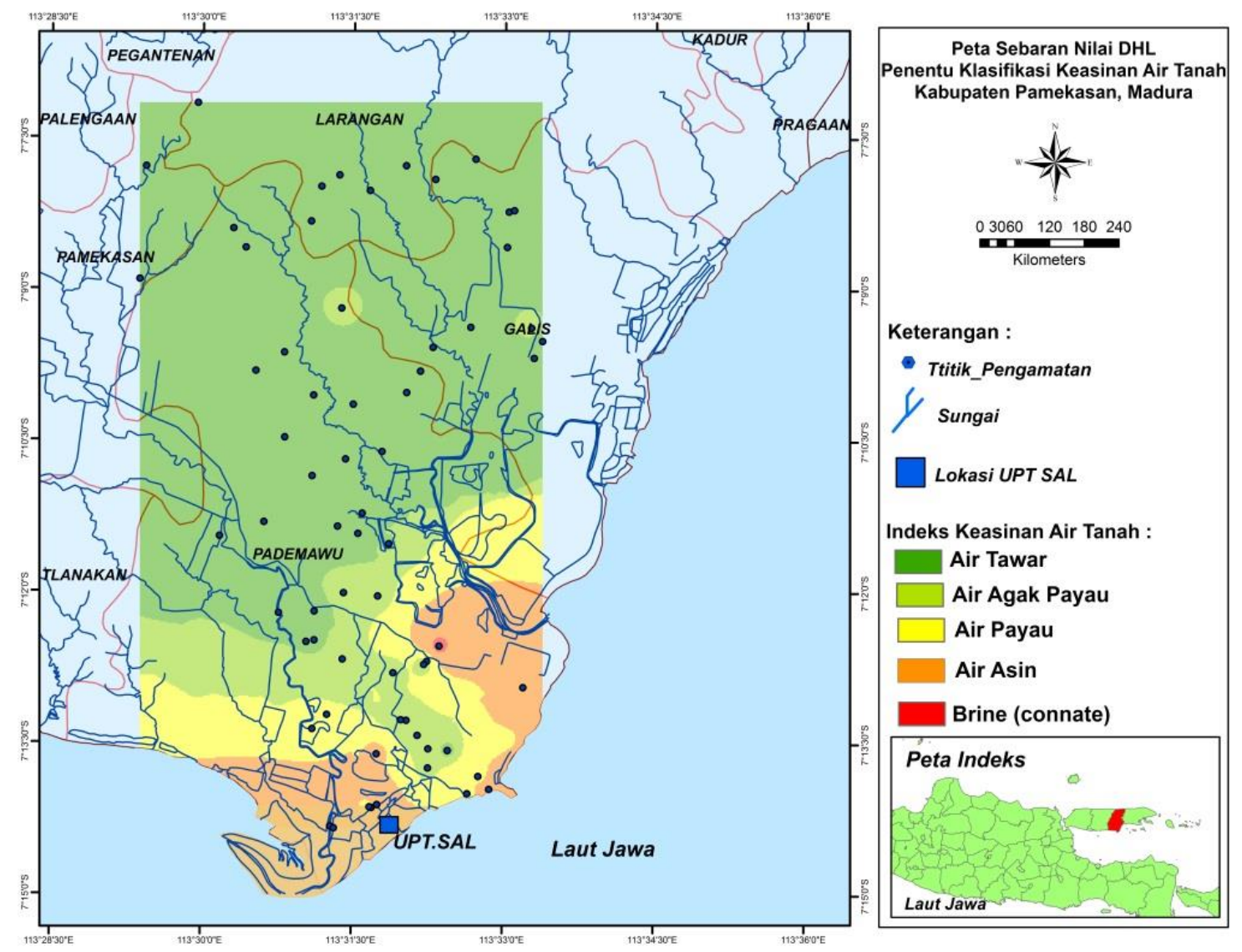

Gambar 3. Peta Sebaran Nilai DHL untuk Klasifikasi Tingkat Keasinan Air Tanah

Daerah sebaran air tanah asin hingga payau menempati akuifer berupa lempung pasiran yang merupakan endapan alluvial dengan permeabilitas umumnya rendah dan topografi permukaan tanah datar hingga landai, sehingga sangat rentan terhadap intrusi air laut. Beberapa lokasi juga memiliki kategori tingkat keasinan air tanah agak payau dengan nilai DHL lebih dari 1500 $\mu \mathrm{S} / \mathrm{cm}$ berada diantara kelompok air tanah payau, yaitu di desa Pademawu, Majungan, Mansinan, Pokong dan Murtajih. Keberadaan kelompok air tanah agak payau berdasarkan pola sebaran nilai DHL berada pada bagian atas pola nilai DHL payau. Air tanah agak payau didominasi oleh akuifer berupa pasir gampingan hingga lempung gampingan, namun sebagian juga masih masuk ke dalam sistem akuifer endapan alluvial. Selain perbedaan sistem batuan penyusun akuifer jarak antara sumur dengan air laut juga menjadi salah satu faktor penyebab perbedaan tingkat keasinan air tanah.

Kelompok air tanah bersifat tawar memiliki nilai DHL kurang dari $1500 \mu \mathrm{S} / \mathrm{cm}$, berada pada bagian utara daerah penelitian, yang merupakan kelompak akuifer dalam. Kedalaman muka air tanah pada kelompok ini rata-rata berkisar lebih dari $10 \mathrm{~m}$. Litologi penyusun akuifer ini masuk dalam dua formasi batuan yaitu Formasi Pamekasan (Qpp) yang tersusun atas litologi pasir, gamping hingga lempung dan Formasi Madura (Tpm) tersusun atas batugamping terumbu dan gamping dolomitan (Azis et al., 1992). Sifat air tanah pada daerah tersebut tawar dapat diinterpretasikan bahwa sistem akuifer dalam memiliki tingkat kerentanan yang sangat rendah, dan jarak dengan laut cukup jauh merupakan salah satu faktor air tanah pada daerah Utara penelitian yang meliputi kecamatan Larangan, Galis, Tlanakan bersifat tawar. Namun terlihat 
pada peta sebaran nilai DHL adanya titik air tanah dengan sifat agak payau di antara kelompok air tanah tawar diinterpretasikan kemungkinan adanya campuran air connate yang terperangkap pada saat proses sedimentasi berlangsung.

Pengujian laboraturium yang dilakukan di Lab. Teknik Lingkungan ITB terhadap beberapa sampel airtanah untuk mengetahui nilai konsentrasi kation ( $\mathrm{Na}, \mathrm{Ca}, \mathrm{Mg}$ dan $\mathrm{K}$ ) dan anion $\left(\mathrm{Cl}, \mathrm{SO}_{4}, \mathrm{CO}_{3}\right.$ dan $\left.\mathrm{HCO}_{3}\right)$ pada 15 sampel airtanah yang diambil berdasarkan pembagian zonasi kelompok akuifer airtanah dangkal dan airtanah dalam. Sampel airtanah untuk analisis hidrokimia sebanyak 8 titik sampel untuk air tanah dangkal dan 7 sampel untuk airtanah dalam. Hasil analisis laboraturium tersebut kemudian dilakukan perhitungan dengan metode khlorida Tabel 3. Nilai khlorida-bicarbonat ratio air tanah dangkal di Wilayah Pademawu dan Sekitarnya

\begin{abstract}
bicarbonate ratio, serta analisis menggunakan diagram Trilinier Piper.

Hasil perhitungan metode Khlorida (Cl) Bicarbonat $\left(\mathrm{HCO}_{3}\right)$ Ratio sebagaimana tercantum dalam Tabel 3 dan Tabel 4 terlihat bahwa intrusi air laut pada akuifer dangkal telah terjadi hampir di seluruh wilayah Padelegan, Pademawu bagian selatan dengan tingkat penyusupan air laut tinggi hingga sedikit, kondisi wilayah tersebut yang sangat berdekatan dengan pantai dan laut sehingga memungkinkan terjadinya penyusupan air laut. Sedangkan akuifer dalam berada pada bagian utara daerah penelitian tidak terdeteksi adanya gejala intrusi air laut dan masih dalam batasan tidak memiliki kerentanan terhadap penyusupan air laut.
\end{abstract}

\begin{tabular}{lrc}
\hline \multicolumn{1}{c}{ Nama Lokasi } & \multicolumn{1}{c}{$\mathbf{R}$} & Tingkat Penyusupan Air Laut \\
\hline Padelegan & 0.501592357 & Terjadi penyusupan air laut sedikit \\
Padelegan & 36.549019610 & Air laut \\
Padelegan & 5.470588235 & Terjadi penyusupan air laut agak tinggi \\
Majungan & 0.913934426 & Terjadi penyusupan air laut sedikit \\
Mangunan & 0.759002770 & Terjadi penyusupan air laut sedikit \\
Murtajih & 0.225818182 & Air tanah tawar \\
Bunder & 2.125000000 & Terjadi penyusupan air laut sedang \\
Pademawu Timur & 0.082704403 & Air tanah tawar \\
\hline
\end{tabular}

Tabel 4. Nilai khlorida-bicarbonat ratio air tanah dalam di Wilayah Pademawu dan Sekitarnya

\begin{tabular}{lcc}
\hline \multicolumn{1}{c}{ Nama Lokasi } & $\mathbf{R}$ & Tingkat Penyusupan Air Laut \\
\hline Pamekasan & 0.016909091 & Tidak terdeteksi \\
Galis & 0.202730375 & Tidak terdeteksi \\
Sentol & 0.134615385 & Tidak terdeteksi \\
Pletong & 0.104395604 & Tidak terdeteksi \\
Blumbungan & 0.110326087 & Tidak terdeteksi \\
Kuwel & 0.076447876 & Tidak terdeteksi \\
Galis & 0.069827586 & Tidak terdeteksi \\
\hline
\end{tabular}

Hasil pengukuran di lapangan juga menunjukkan bahwa di daerah Padelegan, Pademawu dan sekitarnya yang terindikasi adanya proses intrusi air laut. Hasil pengukuran $\mathrm{DHL}$ menunjukkan nilai lebih dari $15.000 \mu \mathrm{S} / \mathrm{cm}$ dengan nilai $\mathrm{R}$ rata-rata lebih dari 0,5 hal tersebut membuktikan bahwa pada sistem air tanah pada daerah tersebut mengalami proses penyusupan air laut. Sedangkan pada daerah bagian Utara daerah penelitian yang mencakup kecamatan Galis, Tlanakan, Pamekasan dan Larangan tidak terindikasi mengalami proses penyusupan air laut. Indikasi tersebut diperkuat dengan nilai Khlorida - Bicarbonat Ratio yang memiliki nilai kurang dari 0.5 
bahkan hingga mencapai nilai $\mathrm{R}$ lebih dari 0.01 yang berarti bahwa air tanah di daerah tersebut tidak terdeteksi mengalami proses intrusi air laut. Selain dari hasil perbandingan nilai Khlorida - Bicarbonat Ratio.

Hasil pengolahan data nilai Kation dan Anion airtanah kemudian divisualisasikan dengan diagram Triliener Piper (Gambar 4), terlihat bahwa air tanah di daerah Pademawu dan Sekitarnya diindikasikan mengalami proses intrusi air laut. Hal tersebut didasarkan letak titik pada diagram Trilinier Piper yang semakin ke arah zona tengah (zona pencampuran) sebagaimana dikemukakan oleh Sihwanto (1991).rata suhu permukaan air laut yang normal, yaitu berkisar antara $25,6-32^{\circ} \mathrm{C}$.

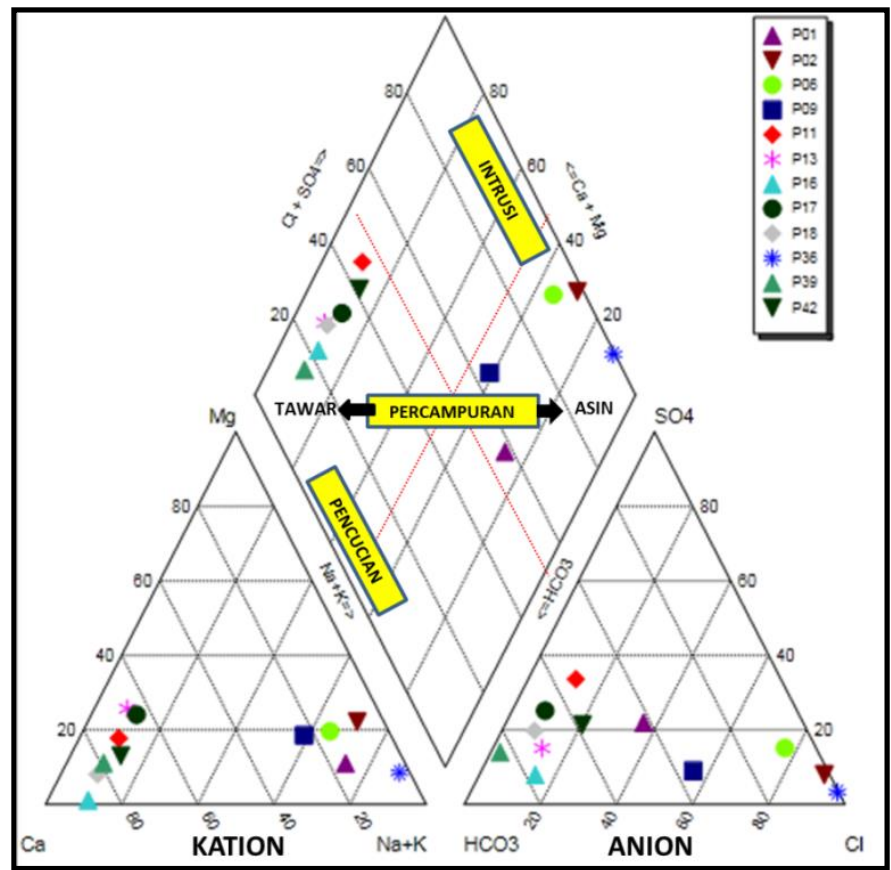

\begin{tabular}{|lccc|}
\hline P01 & Padelegan & P39 & Pamekasan \\
P02 & Padelegan & P42 & Galis \\
P06 & Padelegan & P11 & Sentol \\
P09 & Majungan & P13 & Pletong \\
P16 & Blumbungan & P18 & Galis \\
P17 & Kuwel & & \\
\hline
\end{tabular}

Gambar 4. Diagram trilinier piper air tanah pada akuifer dangkal dan dalam di Pademawu dan

Sekitarnya

Zonasi aliran air tanah dangkal bagian Pademawu timur (tengah) menunjukkan bahwa sampel air tanah yang diambil dari beberapa sumur di wilayah Pademawu timur, Tanjung dan Jumiang mengalami intrusi air laut namun masih dalam batasan sedikit. Hal tersebut ditunjukkan bahwa sampel air tanah tersebut berada pada zona tengah (zona pencampuran air tanah dan air asin). Pada diagram Trilinier Piper memperlihatkan semakin kearah kanan yang menyatakan semakin kuat pengaruh air asin sehingga dapat diindikasikan telah terjadi proses intrusi air laut. Namun pada kawasan air tanah bagian tengah terletak pada bagian tengah diagram Trilinier Piper yang mengindikasikan proses penyusupan air laut masih sedikit sehingga air bersifat payau hingga agak payau. Nilai DHL pada zona tersebut menunjukkan nilai lebih besar dari $1500 \mu \mathrm{S} / \mathrm{cm}$ dan kurang dari 15.000 $\mu \mathrm{S} / \mathrm{cm}$. Hal tersebut diperkuat dengan nilai Khlorida - Bicarbonat Ratio pada zona tengah ini memiliki nilai 0,5 sehingga mengindikasikan terjadinya proses penyusupan air laut sedikit. 
Dengan demikian dapat disimpulkan bahwa air tanah asin pada wilayah Padelegan, Pademawu terbentuk karena adanya proses intrusi air laut. Untuk aliran air tanah dangkal pada bagian tenggara dan barat, terlihat berada pada bagian zona tengah diagram Trilinier Piper yang merupakan zona pencampuran air tawar dan air asin. Sedangkan pada bagian selatan daerah penelitian yaitu kawasan pesisir Padelegan, Pademawu berada pada bagian zona kanan Trilinier Piper hal tersebut mengindikasikan terjadinya proses penyusupan air laut tinggi. Untuk akuifer dalam pada berada pada bagian kiri zona Trilinier Piper dan diinterpretasikan tidak terjadi dan tidak terindikasi adanya proses penyusupan air laut dan air tanah bersifat tawar.

\section{KESIMPULAN DAN SARAN}

Di wilayah pesisir Padelegan, Pademawu dan Sekitarnya, air tanah tawar tidak dijumpai pada kawasan tersebut, namun pada kawasan tersebut masuk dalam kategori air tanah asin hingga agak payau dengan nilai $\mathrm{DHL}$ untuk air tanah asin > $15.000 \mu \mathrm{S} / \mathrm{cm}$ hingga nilai DHL $5000 \mu \mathrm{S} / \mathrm{cm}$ yang bersifat agak payau, wilayah yang masuk dalam kelompok tersebut berada pada Padelegan, Jumiang, Tanjung, dan Pademawu Timur dengan sistem akuifer air tanah dangkal yang tersusun atas endapan aluvial. Sedangkan untuk air tanah tawar berada pada bagian utara daerah penelitian yang meliputi kecamatana Galis, Tlanakan, Pamekasan dana Larangan, dengan nilai DHL kurang dari $1500 \mu \mathrm{S} / \mathrm{cm}$ dan termasuk dalam kelompok sistem akuifer air tanah dalam dan tersusun atas pasir gampingan, lempung hingga gamping terumbu dan gamping dolomitan.

Berdasarkan analisis fasies hidrokimia diketahui bahwa airtanah dangkal di daerah Pademawu dan Sekitarnya telah pengalami proses penyusupan air laut atau intrusi air laut secara merata pada bagian selatan dan bagian tepi pantai. Wilayah bagian Tenggara dan Barat memperlihatkan adanya tandatanda penyusupan air laut, namun belum sampai membuat air tanah menjadi asin. Sedangkan untuk akuifer dalam tidak terdeteksi adanya gejala penyusupan air laut terutama pada bagian Utara daerah penelitian.

\section{DAFTAR PUSTAKA}

Azis, S. et al. (1992). Peta Geologi Lembar Tanjungbumi dan Pamekasan, Jawa. Bandung. Pusat Penelitian dan Pengembangan Geologi

Delinom, R. (Ed). (2007). Sumber Daya Air Di Wilayah Pesisir Dan Pulau-Pulau Kecil Di Indonesia. Jakarta. Lembaga Ilmu Pengetahuan Indonesia, Pusat Penelitian Geoteknologi, LIPI Press

Mandel, S., \& Shiftan, Z. L. (1981). Groundwater Resources: Investigation and Development. Academic Press. London. 256 hal

Irham, M. et al. (2006). Pemetaan Sebaran Air Tanah Asin Pada Aqiufer Dalam Di Wilayah Semarang Bawah. Jurnal Berkala Fisika, 9(3), 137-143

Saputra, S. (1998). Telaah Geologi Terhadap banjir dan Rob Kawasan Pantai Semarang. Jurnal IImu Kelautan, 3(10), 85-92.

Sihwanto \& Satriyo. (1991). Metode Penentuan Penyebab Keasinan Air Tanah: Studi Kasus Daerah Dataran Pantai Dumai, Riau. Kumpulan Makalah Ikatan Ahli Geologi Indonesia. Bandung. Hal 2640.

Sihwanto. (1991). Parameter Akuifer dan Aliran Airtanah, Diklatsar Hidrogeologi Kanwil Pertambangan dan Energi. Direktorat Geologi Tata Lingkungan Dirjen Geologi dan Sumberdaya Mineral, Dept. Pertambangan dan Energi Republik Indonesia

Situmorang, R. I., Agustianto, D. A., Suparman, M. (1992). Peta Geologi Lembar Waru - Sumenep Jawa. Bandung. Pusat Penelitian dan Pengembangan Geologi 